\title{
Allelopathic activity of the leaf powder of Ficus nitida on the growth and yield of Vicia faba and associated weeds
}

\author{
R. R. El-Masry, S. A. A. Ahmed, Kowther G. El-Rokiek ${ }^{*}$, Nadia K. Messiha and Sanaa A. Mohamed
}

\begin{abstract}
Background: Faba bean weeds are considered as serious pests that lead to pronounced damages to its agricultural production since they consume water and nutrients from the soil, reducing not only the yield but also the quality of the crops. So, the aim of this investigation is to control the weeds associated with faba bean plants.

Materials/methods: Two pot experiments were carried out during two successive winter seasons of 2016/2017 and 2017/2018 in the greenhouse of the National Research Centre, Dokki, Giza, Egypt. Treatments were applied by incorporating the dry leaf powder of Ficus nitida to the soil surface of pots at the rate of $(0,10,20,30,40,50$, and $60 \mathrm{~g} / \mathrm{kg}$ soil).

Results: All concentrations used pronouncedly decreased the fresh and dry weight of both Phalaris minor and Malva parviflora. On the other hand, Vicia faba growth as well as its yield and yield components were increased with most concentrations used as compared to their mixed controls. Treatments of 20, 30, and $40 \mathrm{~g} / \mathrm{kg}$ soil, from $F$. nitida leaf powder, respectively recorded the highest increases in the most growth characters of $V$. faba with both weeds (P. minor and M. parviflora) at the two growth ages when compared to the healthy control. Also, the best results in all $V$. faba yield components were recorded with $20 \mathrm{~g} / \mathrm{kg}$ soil of $F$. nitida treatment.

Conclusion: The results of the present study indicate the possibility of using the allelopathic activity of the leaf powder of Ficus nitida as a selective bioherbicide for controlling annual weeds accompanied Vicia faba plants.
\end{abstract}

Keywords: Allelopathy, Ficus nitida, Vicia faba, Phalaris minor, Malva parviflora, Phenolic content, Flavonoids

\section{Background}

Allelopathy has beneficial or harmful effects on plants due to release of allelochemicals which are secondary metabolites, which is present in all plant tissues including leaves, stems, flowers, roots, and seeds (Manikandan and Jayakumar 2011; Mohsin et al. 2016). Allelochemicals are now being used as biopesticides, bioherbicides, and also as growth promoters. Therefore, it is another emerging area of research since most of the chemicals as biopesticides or bioherbicides are known to be specific variety of pests and weeds. The use of allelochemicals as secondary metabolites from plants for this purpose would be environmentally

\footnotetext{
*Correspondence: kowtharelrokiek@gmail.com; ahmed_ezat2000@yahoo.com

Botany Department, National Research Centre, El-Buhouth St., Dokki, P.O. Box 12622, Giza, Egypt
}

friendly, since natural chemicals are renewable and easily degradable (Manikandan and Jayakumar 2011).

Allelopathy is simply a natural process of inhibition or stimulation of plants by the action of allelochemicals which are produced and released to the environment by different plants (Zeng et al. 2008; Majeed et al. 2017). Moreover, the inhibition or stimulation efficiency of these allelochemicals depends on their type, concentration, and the plants which respond to these allelochemicals (Dawood et al. 2012; Majeed et al. 2012; Muhammad and Majeed 2014; El-Masry et al. 2015; Ahmed et al. 2018; El-Rokiek et al. 2018; Messiha et al. 2018).

Ficus genus contains about 850 species of woody trees, shrubs, vines, epiphytes, and hemi epiphytes in the family Moraceae. Ficus benghalensis L. (as an example of Ficus species) possess variety of medicinal 
uses. Chemically, F. benghalensis stem and bark contain anthocyanidin derivatives, beta-sitosterolglucoside, and mesoinsitol and aliphatic long-chain ketones (Sankar and Nair 2001; Manoj and Urmila 2008; Vishnu and Anupama 2010). In addition, leaves contain crude protein, crude fibers, calcium oxalate, phosphorus, sterols, flavonoids, phenol, tannins, and saponions in large amounts. Moreover, number of researchers observed its anti-inflammatory, anti-helminitin, anti-histaminic, immunomodulatory, anti-microbial, allelopathic, anti-diabetic, antifungal, and antibacterial activities (Manoj and Urmila 2008; Sharma et al. 2009; Taur and Patil 2009; Uma and Prabhakar 2009; Vishnu and Anupama 2010).

Vicia faba (faba bean) is one of the most important legumes in the world especially in developing countries. It is a leading source of food protein. It is also a rich source of dietary fiber, minerals, and some vitamins (Gepts et al. 2008).

On the other hand, weeds are considered a serious pest that leads to pronounced damage to agricultural production because it consumes nutrients from the soil. Thus, reduces the yield of the crops, in addition it reduces the quality and quantity of the crop (Siddiqui et al. 2009; Messiha et al. 2018).

The aim of the present investigation is to assess the allelopathic potentiality of the leaves of Ficus nitida (a widely and common tree in Egypt) on the growth of Vicia faba associated by two annual weeds Phalaris minor and Malva parviflora.

\section{Materials and methods}

Two pot experiments were carried out during two successive winter seasons of 2016/2017 and 2017/ 2018 in the greenhouse of the National Research Centre, Dokki, Giza, Egypt, to study the possibility of controlling two weeds, i.e., Phalaris minor and Malva parviflora growing with Vicia faba by using the dry leaf powder of Ficus nitida. Vicia faba seeds (var. Giza 843) were obtained from Agricultural Research Centre, Giza, Egypt. Dry leaves of Ficus nitida was grinded to fine powder and was immediately incorporated to the soil surface of the pots before sowing at the rate of $0,10,20,30,40,50$, and $60 \mathrm{~g} /$ $\mathrm{kg}$ soil. The pots, $30 \mathrm{~cm}$ in diameter and $30 \mathrm{~cm}$ in height, contained equal amounts of sieved soil (2: 1 $v / v$ clay and sand). Seven seeds of $V$. faba were sown on 20th and 19th of November in the first and second seasons, respectively. The pots were infested with a constant weight from each weed, i.e., $P$. minor and $M$. parviflora. The seeds of both weeds were sown simultaneously and mixed thoroughly at a depth $2 \mathrm{~cm}$ in the soil. The experiment consisted of eight treatments for each weed including two untreated controls, healthy plant (weed-free faba bean), faba bean with $P$. minor or $M$. parviflora (unweeded treatment). The other six treatments were leaf powder of Ficus nitida at concentrations 10, 20, 30, 40, 50 , and $60 \mathrm{~g} / \mathrm{kg}$ soil. All pots were distributed in a complete randomized design. Faba bean seedlings were thinned 2 weeks after sowing so that three homogeneous seedlings were left per pot. Three replicates were collected from each treatment at 30 and 60 days after sowing and at harvest. The normal cultural practices of growing $V$. faba plants were followed especially fertilization and irrigation.

\section{Weed characters studied}

Three replicates were collected from each treatment at 30 and 60 days after sowing (DAS), fresh and dry weight of both $P$. minor and M. parviflora (g/pot) were recorded.

\section{Vicia faba characters studied Plant growth}

Samples from $V$. faba plants were collected from each treatment at 30 and 60 (DAS) to determine plant height $(\mathrm{cm})$, number of leaves/plant, number of branches/plant, as well as fresh and dry weight of plant (g).

\section{Yield and yield components}

On April 27 and 25 in the first and second season, respectively, samples from $V$. faba plants were taken at harvest from each treatment to determine the number of pods/plant, weight of pods/plant (g), length of pod $(\mathrm{cm})$, number of seeds/ pod, weight of seeds/plant (g), weight of seeds/10 pods (g), and weight of 100 seeds (g).

\section{Chemical analysis}

Determination of total phenolic contents and total

flavonoids in the leaf powder of F. nitida

Total phenol and total flavonoids were determined in the leaf powder of $F$. nitida according to Srisawat et al. (2010).

\section{Statistical analysis}

Data of the two seasons were subjected to analysis of variance (ANOVA) according to Gomez and Gomez (1984), using CoStat software program. The differences among means were compared using LSD test at 0.05 probability level.

\section{Results}

\section{Weed growth characters}

The results in Tables 1 and 2 showed that all concentrations used from the leaf powder of Ficus nitida (10 to $60 \mathrm{~g} / \mathrm{kg}$ soil) significantly decreased fresh and dry weight of both weeds, i.e., Phalaris 
Table 1 Effect of Ficus nitida leaf powder on fresh and dry weight of grassy leaved weed Phalaris minor associated with Vicia faba plants (average of the two seasons)

\begin{tabular}{|c|c|c|c|c|c|}
\hline \multicolumn{2}{|l|}{ Treatments } & \multicolumn{2}{|c|}{ At 30 DAS } & \multicolumn{2}{|c|}{ At 60 DAS } \\
\hline Plants & Concentrations of Ficus nitida ( $\mathrm{g} / \mathrm{kg}$ soil) & $\mathrm{FW}(\mathrm{g})$ & DW (g) & FW (g) & DW $(g)$ \\
\hline Phalaris minor only & - & 6.45 & 1.36 & 17.26 & 9.40 \\
\hline \multirow[t]{7}{*}{ Phalaris minor + Vicia faba } & - & 4.35 & 0.71 & 8.75 & 3.48 \\
\hline & 10 & 3.92 & 0.58 & 6.57 & 2.59 \\
\hline & 20 & 2.99 & 0.47 & 6.01 & 2.38 \\
\hline & 30 & 2.51 & 0.45 & 5.53 & 2.21 \\
\hline & 40 & 1.88 & 0.33 & 4.73 & 1.88 \\
\hline & 50 & 1.57 & 0.30 & 4.42 & 1.74 \\
\hline & 60 & 1.26 & 0.16 & 2.66 & 1.05 \\
\hline LSD at $5 \%$ & & 0.83 & 0.16 & 1.31 & 0.78 \\
\hline
\end{tabular}

minor and Malva parviflora at both growth ages (30 and $60 \mathrm{DAS})$, except the lowest concentration (10 g/ $\mathrm{kg}$ soil) with $P$. minor at $30 \mathrm{DAS}$, as compared to the mixed control. The rate of reduction in weed growth of both $P$. minor and $M$. parviflora depends on the concentration used. The maximum reduction in the fresh and dry weight of both weeds at both growth ages was recorded with the highest concentration $(60 \mathrm{~g} / \mathrm{kg}$ soil) of $F$. nitida leaf powder, that reached to 69.6 and $69.8 \%$ for $P$. minor and 79.5 and $80.3 \%$ for $M$. parviflora respectively, as compared to their corresponding control at the second growth age (60 DAS).

\section{Vicia faba growth}

The results recorded in Tables 3 and 4 illustrated that most $V$. faba growth characters, represented by plant height $(\mathrm{cm})$, number of leaves/plant, number of branches/plant, as well as fresh and dry weight/plant (g), were significantly increased with all concentrations of F. nitida leaf powder (10 to $60 \mathrm{~g} / \mathrm{kg}$ soil) as compared to their mixed control with both weeds, $P$. minor and $M$. parviflora at both growth ages (30 and 60 DAS). Treatments of 20, 30, and $40 \mathrm{~g} / \mathrm{kg}$ soil, from $F$. nitida leaf powder, respectively recorded the highest increases in the most growth characters of $V$. faba with both weeds ( $P$. minor and M. parviflora) at the two growth ages when compared to the healthy control. It is worthy to mention that the best results in most growth characters at the two growth ages with both weeds was recorded with treatment $(20 \mathrm{~g} / \mathrm{kg}$ soil $)$ from F. nitida leaf powder as compared with healthy control. At 60 DAS, the increases in the dry weight of $V$. faba plant due to this treatment reached to 12.27 and $25.38 \%$, respectively over the healthy control with $P$. minor and $M$. parviflora weeds.

\section{Vicia faba yield and yield components}

The results of yield and yield components, i.e., number of pods/plant, weight of pods/plant $(\mathrm{g})$, length of pod $(\mathrm{cm})$, number of seeds/pod, weight of seeds/ plant $(\mathrm{g})$, weight of seeds $/ 10$ pods $(\mathrm{g})$, and weight of 100 seeds (g) recorded in Tables 5 and 6, showed

Table 2 Effect of Ficus nitida leaf powder on fresh and dry weight of broad leaved weed Malva parviflora associated with Vicia faba plants (average of the two seasons)

\begin{tabular}{|c|c|c|c|c|c|}
\hline \multicolumn{2}{|l|}{ Treatments } & \multicolumn{2}{|c|}{ At 30 DAS } & \multicolumn{2}{|c|}{ At 60 DAS } \\
\hline Plants & Concentrations of Ficus nitida (g/kg soil) & FW (g) & DW (g) & FW (g) & DW (g) \\
\hline Malva parviflora only & - & 6.25 & 1.05 & 18.45 & 3.11 \\
\hline \multirow[t]{7}{*}{ Malva parviflora + Vicia faba } & - & 3.13 & 0.46 & 6.65 & 1.17 \\
\hline & 10 & 2.12 & 0.34 & 4.17 & 0.72 \\
\hline & 20 & 1.75 & 0.27 & 3.47 & 0.61 \\
\hline & 30 & 1.56 & 0.24 & 2.65 & 0.45 \\
\hline & 40 & 1.26 & 0.19 & 2.26 & 0.38 \\
\hline & 50 & 0.85 & 0.13 & 2.07 & 0.34 \\
\hline & 60 & 0.73 & 0.10 & 1.36 & 0.23 \\
\hline LSD at $5 \%$ & & 0.78 & 0.06 & 0.94 & 0.35 \\
\hline
\end{tabular}


Table 3 Effect of Ficus nitida leaf powder on some growth parameters of Vicia faba plants associated with Phalaris minor at 30 and 60 days after sowing (average of the two seasons)

\begin{tabular}{|c|c|c|c|c|c|c|}
\hline \multicolumn{2}{|l|}{ Treatments } & \multicolumn{5}{|c|}{ Growth parameters of Vicia faba } \\
\hline Plants & $\begin{array}{l}\text { Concentrations of Ficus nitida (g/kg } \\
\text { soil) }\end{array}$ & $\begin{array}{l}\text { Plant height } \\
(\mathrm{cm})\end{array}$ & $\begin{array}{l}\text { No. of leaves/ } \\
\text { plant }\end{array}$ & $\begin{array}{l}\text { No. of branches/ } \\
\text { plant }\end{array}$ & $\begin{array}{l}\text { F.W. of plant } \\
\text { (g) }\end{array}$ & $\begin{array}{l}\text { D.W. of plant } \\
\text { (g) }\end{array}$ \\
\hline \multicolumn{7}{|l|}{ At 30 DAS } \\
\hline Vicia faba only & - & 33.75 & 10.8 & 1.58 & 8.83 & 1.22 \\
\hline \multirow{7}{*}{$\begin{array}{l}\text { Vicia faba }+ \text { Phalaris } \\
\text { minor }\end{array}$} & - & 24.63 & 8.0 & 1.10 & 6.52 & 0.78 \\
\hline & 10 & 29.38 & 10.4 & 1.40 & 8.39 & 1.06 \\
\hline & 20 & 35.38 & 11.6 & 1.73 & 10.12 & 1.38 \\
\hline & 30 & 34.86 & 11.3 & 1.71 & 9.68 & 1.31 \\
\hline & 40 & 34.29 & 11.0 & 1.62 & 8.94 & 1.26 \\
\hline & 50 & 28.88 & 10.2 & 1.27 & 8.35 & 1.04 \\
\hline & 60 & 27.25 & 9.6 & 1.15 & 8.01 & 0.99 \\
\hline LSD at $5 \%$ & & 1.43 & 0.91 & 0.20 & 1.12 & 0.14 \\
\hline \multicolumn{7}{|l|}{ At 60 DAS } \\
\hline Vicia faba only & - & 59.15 & 19.52 & 2.03 & 22.65 & 5.95 \\
\hline \multirow{7}{*}{$\begin{array}{l}\text { Vicia faba + Phalaris } \\
\text { minor }\end{array}$} & - & 37.17 & 15.20 & 1.38 & 12.28 & 3.32 \\
\hline & 10 & 52.80 & 18.00 & 1.90 & 20.27 & 5.23 \\
\hline & 20 & 63.75 & 20.33 & 2.33 & 24.97 & 6.68 \\
\hline & 30 & 63.25 & 20.00 & 2.24 & 23.83 & 6.36 \\
\hline & 40 & 61.28 & 19.67 & 2.07 & 22.74 & 5.99 \\
\hline & 50 & 50.81 & 16.92 & 1.83 & 19.65 & 5.16 \\
\hline & 60 & 45.20 & 15.87 & 1.67 & 18.04 & 4.76 \\
\hline LSD at $5 \%$ & & 1.69 & 1.45 & 0.18 & 1.52 & 0.86 \\
\hline
\end{tabular}

that all applied treatments used of F. nitida leaf powder (from 10 to $60 \mathrm{~g} / \mathrm{kg}$ soil) significantly increased all yield parameters of $V$. faba, except the highest concentration $(60 \mathrm{~g} / \mathrm{kg}$ soil), as compared to their mixed control with both weeds, $P$. minor and $M$. parviflora. The best results in all $V$. faba yield components were recorded with $20 \mathrm{~g} / \mathrm{kg}$ soil of $F$. nitida treatment. Not only this treatment alleviated the harmful effect of both weeds ( $P$. minor and $M$. parviflora) but also significantly increased all plant yield parameters over the corresponding healthy control. The maximum increases in the weight of seeds/ plant (g) and weight of seeds/10 pods (g) of $V$. faba associated with $P$. minor weed reached to 41.28 and $36.0 \%$, respectively, while with $M$. parviflora weed reached to 48.16 and $50.40 \%$, respectively over the corresponding healthy control. Treatments with 30 and $40 \mathrm{~g} / \mathrm{kg}$ soil from $F$. nitida leaf powder also achieved good results with all $V$. faba yield components, associated with both weeds, equal or exceed than the corresponding healthy control in some yield components.

Therefore, it could be concluded that F. nitida leaf powder at $(20,30$, and $40 \mathrm{~g} / \mathrm{kg}$ soil) incorporated to the soil caused moderate reduction in the growth of both weeds ( $P$. minor and $M$. parviflora) as shown in Tables 1 and 2 and consequently accompanied by the maximum increases in $V$. faba growth as well as yield and yield components (Tables 3, 4, 5, and 6).

\section{Discussion}

Our previous work at the Botany department of the National Research Centre of Egypt showed clearly that using the dry leaves and seeds powder of some allelopathic plants achieved good results in controlling some annual, perennial, as well as parasitic weeds associated different economic crops and could improve their growth as well as yield (El-Masry et al. 2015; Ahmed et al. 2018; Messiha et al. 2018).

The results of the present investigation reveal that Ficus nitida leaf powder possess to great extent allelopathic effect in controlling the growth of the two annual weeds Phalaris minor and Malva parviflora associating Vicia faba plants when added to the soil. The rate of reduction in the fresh and dry weight of both weeds at the two ages increased by increasing the F. nitida leaf powder concentration. Maximum 
Table 4 Effect of Ficus nitida leaf powder on some growth parameters of Vicia faba plants associated with Malva parviflora at 30 and 60 days after sowing (average of the two seasons)

\begin{tabular}{|c|c|c|c|c|c|c|}
\hline \multicolumn{2}{|l|}{ Treatments } & \multicolumn{5}{|c|}{ Growth parameters of Vicia faba } \\
\hline Plants & $\begin{array}{l}\text { Concentrations of Ficus nitida (g/ } \\
\text { kg soil) }\end{array}$ & $\begin{array}{l}\text { Plant height } \\
(\mathrm{cm})\end{array}$ & $\begin{array}{l}\text { No. of leaves/ } \\
\text { plant }\end{array}$ & $\begin{array}{l}\text { No. of branches/ } \\
\text { plant }\end{array}$ & $\begin{array}{l}\text { F.W. of plant } \\
\text { (g) }\end{array}$ & $\begin{array}{l}\text { D.W. of plant } \\
\text { (g) }\end{array}$ \\
\hline \multicolumn{7}{|l|}{ At 30 DAS } \\
\hline Vicia faba only & - & 33.75 & 10.8 & 1.58 & 8.83 & 1.22 \\
\hline \multirow{7}{*}{$\begin{array}{l}\text { Vicia faba + Malva } \\
\text { parviflora }\end{array}$} & - & 26.83 & 8.6 & 1.10 & 6.86 & 0.81 \\
\hline & 10 & 30.75 & 10.5 & 1.45 & 8.48 & 1.08 \\
\hline & 20 & 37.67 & 12.5 & 2.03 & 12.18 & 1.62 \\
\hline & 30 & 37.33 & 11.9 & 1.87 & 10.51 & 1.43 \\
\hline & 40 & 34.64 & 11.1 & 1.70 & 9.26 & 1.29 \\
\hline & 50 & 33.57 & 10.6 & 1.53 & 8.54 & 1.10 \\
\hline & 60 & 28.19 & 10.2 & 1.25 & 8.33 & 1.01 \\
\hline LSD at $5 \%$ & & 1.49 & 1.1 & 0.18 & 1.21 & 0.14 \\
\hline \multicolumn{7}{|l|}{ At 60 DAS } \\
\hline Vicia faba only & - & 59.15 & 19.52 & 2.03 & 22.65 & 5.95 \\
\hline \multirow{7}{*}{$\begin{array}{l}\text { Vicia faba + Malva } \\
\text { parviflora }\end{array}$} & - & 39.32 & 15.35 & 1.57 & 15.31 & 3.91 \\
\hline & 10 & 55.63 & 18.33 & 1.92 & 21.44 & 5.63 \\
\hline & 20 & 67.82 & 22.40 & 2.60 & 27.98 & 7.46 \\
\hline & 30 & 67.43 & 20.67 & 2.35 & 26.95 & 7.18 \\
\hline & 40 & 62.25 & 19.80 & 2.18 & 23.24 & 6.13 \\
\hline & 50 & 56.84 & 18.83 & 2.00 & 21.52 & 5.67 \\
\hline & 60 & 49.22 & 16.03 & 1.73 & 18.55 & 4.89 \\
\hline LSD at $5 \%$ & & 1.93 & 1.66 & 0.19 & 1.74 & 0.79 \\
\hline
\end{tabular}

reduction recorded with the highest $F$. nitida leaf powder concentration $(60 \mathrm{~g} / \mathrm{kg}$ soil) reached to 69.8 and $80.3 \%$ respectively in the dry weight of $P$. minor and M. parviflora at 60 DAS as compared to their mixed control (Tables 1 and 2). These results are in agreement with the results reported by Manikandan and Jayakumar (2011); they showed the inhibitory effect of the methanolic leaf and bark extracts of $F$. bengalensis on seed germination, shoot and root length, as well as the biomass weight in Ipomoea pentaphylla seedling. They concluded that the inhibitory effect on weed species is directly proportional to increase the concentration used and this may be due to the presence of methanolic soluble allelochemicals

Table 5 Effect of Ficus nitida leaf powder on yield components of Vicia faba plants associated with Phalaris minor at harvest (average of the two seasons)

\begin{tabular}{|c|c|c|c|c|c|c|c|c|}
\hline \multicolumn{2}{|l|}{ Treatments } & \multicolumn{7}{|c|}{ Yield components of Vicia faba } \\
\hline Plants & $\begin{array}{l}\text { Concentrations of Ficus } \\
\text { nitida ( } / \mathrm{kg} \text { soil) }\end{array}$ & $\begin{array}{l}\text { No. of } \\
\text { pods/plant }\end{array}$ & $\begin{array}{l}\text { Wt. of pods/ } \\
\text { plant }(\mathrm{g})\end{array}$ & $\begin{array}{l}\text { Length of } \\
\operatorname{pod}(\mathrm{cm})\end{array}$ & $\begin{array}{l}\text { No. of } \\
\text { seeds/pod }\end{array}$ & $\begin{array}{l}\text { Wt. of seeds/ } \\
\text { plant (g) }\end{array}$ & $\begin{array}{l}\text { Wt. of seeds/10 } \\
\text { pods (g) }\end{array}$ & $\begin{array}{l}\text { Wt. of } 100 \\
\text { seeds (g) }\end{array}$ \\
\hline Vicia faba only & - & 6.8 & 12.16 & 8.70 & 3.71 & 10.32 & 24.16 & 74.15 \\
\hline \multirow{7}{*}{$\begin{array}{l}\text { Vicia faba }+ \\
\text { Phalaris minor }\end{array}$} & - & 3.5 & 6.69 & 4.70 & 1.92 & 5.15 & 9.24 & 62.18 \\
\hline & 10 & 6.1 & 10.97 & 7.40 & 3.15 & 9.45 & 19.41 & 71.36 \\
\hline & 20 & 7.7 & 17.47 & 10.90 & 4.21 & 14.58 & 32.86 & 82.27 \\
\hline & 30 & 7.4 & 15.26 & 10.60 & 4.00 & 12.81 & 29.16 & 78.54 \\
\hline & 40 & 7.0 & 12.81 & 10.00 & 3.74 & 10.46 & 27.22 & 74.98 \\
\hline & 50 & 5.8 & 9.57 & 6.20 & 2.81 & 8.19 & 17.56 & 69.75 \\
\hline & 60 & 4.7 & 7.88 & 5.80 & 2.43 & 6.11 & 12.23 & 68.96 \\
\hline LSD at $5 \%$ & & 0.87 & 1.61 & 0.97 & 0.80 & 1.71 & 1.70 & 2.20 \\
\hline
\end{tabular}


Table 6 Effect of Ficus nitida leaf powder on yield components of Vicia faba plants associated with Malva parviflora at harvest (average of the two seasons)

\begin{tabular}{|c|c|c|c|c|c|c|c|c|}
\hline \multicolumn{2}{|l|}{ Treatments } & \multicolumn{7}{|c|}{ Yield components of Vicia faba } \\
\hline Plants & $\begin{array}{l}\text { Concentrations of Ficus } \\
\text { nitida ( } \mathrm{g} / \mathrm{kg} \text { soil) }\end{array}$ & $\begin{array}{l}\text { No. of } \\
\text { pods/plant }\end{array}$ & $\begin{array}{l}\text { Wt. of pods/ } \\
\text { plant (g) }\end{array}$ & $\begin{array}{l}\text { Length of } \\
\text { pod }(\mathrm{cm})\end{array}$ & $\begin{array}{l}\text { No. of } \\
\text { seeds/pod }\end{array}$ & $\begin{array}{l}\text { Wt. of seeds/ } \\
\text { plant (g) }\end{array}$ & $\begin{array}{l}\text { Wt. of seeds/10 } \\
\text { pods }(\mathrm{g})\end{array}$ & $\begin{array}{l}\text { Wt. of } 100 \\
\text { seeds }(\mathrm{g})\end{array}$ \\
\hline Vicia faba only & - & 6.8 & 12.16 & 8.70 & 3.71 & 10.32 & 24.16 & 74.15 \\
\hline \multirow{7}{*}{$\begin{array}{l}\text { Vicia faba }+ \\
\text { Malva parviflora }\end{array}$} & - & 4.0 & 7.02 & 5.0 & 2.00 & 5.45 & 10.54 & 63.24 \\
\hline & 10 & 6.4 & 11.26 & 7.7 & 3.40 & 9.64 & 19.62 & 71.79 \\
\hline & 20 & 9.7 & 18.23 & 11.5 & 4.66 & 15.29 & 36.34 & 83.72 \\
\hline & 30 & 8.3 & 17.85 & 11.2 & 4.32 & 14.87 & 35.02 & 83.16 \\
\hline & 40 & 7.2 & 13.94 & 10.2 & 3.80 & 11.52 & 27.68 & 76.51 \\
\hline & 50 & 6.6 & 11.47 & 8.0 & 3.62 & 9.93 & 22.08 & 72.64 \\
\hline & 60 & 4.9 & 8.52 & 6.0 & 2.75 & 7.06 & 13.22 & 69.25 \\
\hline LSD at $5 \%$ & & 1.0 & 1.29 & 1.2 & 0.97 & 1.16 & 1.92 & 2.06 \\
\hline
\end{tabular}

like phenolic acids. Analysis of the dry leaf extract of F. nitida in the present study revealed the presence of total phenolic acids content $(53.90 \mathrm{mg} / 100 \mathrm{~g}$ dry weight) and total flavonoids (18.83 $\mathrm{mg} / 100 \mathrm{~g}$ dry weight). The reducing effect of $F$. nitida leaf powder on the growth of both weeds, i.e., P. minor and $M$. parviflora, could be attributed to these natural allelochemicals. These results were confirmed by El-Rokiek et al. (2016). Another confirming results were found also by some researcher that leaves and bark extracts of $F$. bengalensis have different allelopathic effect on seed germination percentage and early seedling growth parameters of some economic crop plants as maize (Zea mays), mung bean (Vigna radiata), and sunflower (Helianthus annuus), and these allelopathic effects are due to their allelochemicals mainly the total phenolic acids content that proportion to the concentration (Mohsin et al. 2016; Muhammad et al. 2018).

The results of the present study confirm this idea and reveal that different treatments of $F$. nitida leaf powder not only achieved good results in controlling the two annual weeds, i.e., $P$. minor and $M$. parviflora, but also increased V. faba growth and consequently improved its yield and yield components (Tables 3, 4, 5, and 6) especially at 20, 30, and $40 \mathrm{~g} /$ $\mathrm{kg}$ soil concentrations. It is worthy to mention that improving the plant growth and consequently increasing its yield is not only due to the inhibition of weeds growth by chemical or biological means, that lead to increase the competitive ability of the plant, but also due to the selectivity of the allelochemicals in their action and the plant in their responses (Einhellig 1995). Allelochemicals which inhibit the growth of same or different species at certain concentration may stimulate the growth of same or different species at different concentrations (Ahmed et al. 2014; Bashen 2014; El-Masry et al. 2015; Messiha et al. 2018).

\section{Conclusion}

The results of the present work indicate the possibility of using allelopathic activity of $F$. nitida leaves powder as selective bioherbicide in controlling weeds.

\section{Abbreviations \\ DAS: Days after sowing; DW: Dry weight; F. nitida: Ficus nitida; FW: Fresh weight; V. faba: Vicia faba; Wt.: Weight; var.: Variety}

\section{Acknowledgements}

The authors thank the National Research Centre for providing materials and facilitating this work.

\section{Funding}

The work was self-funded by the authors.

\section{Availability of data and materials}

All data supporting the results are included within the article.

Authors' contributions

All authors have contributed significantly to the idea and design of the study. All authors contributed equally in all parts of this study. All authors read and approved the final manuscript.

Ethics approval and consent to participate

Not applicable.

Consent for publication

Not applicable.

Competing interests

The authors declare that they have no competing interests.

\section{Publisher's Note}

Springer Nature remains neutral with regard to jurisdictional claims in published maps and institutional affiliations. 
Received: 14 March 2019 Accepted: 5 April 2019

Published online: 23 April 2019

\section{References}

Ahmed SA, El-Rokiek KG, El-Masry RR, Messiha NK (2014) The efficiency of allelochemicals in the seed powder of Eruca sativa in controlling weeds in Pisum sativum. Middle East J Agric Res 3(4):757-762

Ahmed SAA, El-Masry RR, Messiha NK, El- Rokiek KG (2018) Evaluating the allelopathic efficiency of the seed powder of Raphanus sativus $L$. in controlling some weeds associating Phaseolus vulgaris L. Int J Environ 7(3):87-94

Bashen AA (2014) Morphological and elements constituent effects of allelopathic activity of some medicinal plants extracts on Zea mays. Int J Curr Res Aca Rev 2(4):135-145

Dawood MG, El-Awadi ME, El-Rokiek KG (2012) Physiological impact of fenugreek, guava and Lantana on the growth and some chemical parameters of sunflower and associated weeds. J Am Sci 8(6):166-174

Einhellig FA (1995) Mechanism of Action of Allelochemical in Allelopathy. In: Allelopathy organisms, processes and application. Am. Chem. Soc, Washington, pp 96-116

El-Masry RR, Messiha NK, El-Rokiek KG, Ahmed SA, Mohamed SA (2015) The allelopathic effect of Eruca sativa mill. Seed powder on growth and yield of Phaseolus vulgaris and associated weeds. Curr Sci Int 4(4):485-490

El-Rokiek KG, El-Masry RR, Ahmed SAA, Mohamed SA, Messiha NK (2018) Allelopathic effects of Allium sativum cloves on growth and yield of Helianthus annuus plants associating Cyperus rotundus. Int J Environ 7(3):78-86

El-Rokiek KG, Saad El-Din SA, Shehata AN, El-Sawi SAM (2016) A study on controlling Setaria viridis and Corchorus olitorius associated with Phaseolus vulgaris growth using natural extracts of Chenopodium album. J Plant Prot Res 56(2):186-192

Gepts P, Aragao F, de Barros E, Blair MW, Brondani R (2008) Genomics of Phaseolus beans, a major source of dietary protein and micronutrients in the tropics. In: Ming R (ed) Genomics of Tropical Crop Plants, Moore, P. Springer, Berlin, pp 113-143

Gomez KA, Gomez AA (1984) Statistical procedures for agriculture research. Wiley, New York

Majeed A, Chaudhry Z, Muhammad Z (2012) Allelopathic assessment of fresh aqueous extracts of Chenopodium album $\mathrm{L}$. for growth and yield of wheat (Triticum aestivum L.). Pk. J Bot 44(1):165-167

Majeed A, Muhammad Z, Hussain M, Ahmad H (2017) In vitro allelopathic effect of aqueous extracts of sugarcane on germination parameters of wheat. Acta Agric Sloven 109(2):349-356

Manikandan M, Jayakumar M (2011) Herbicidal effect of Ficus bengalensis on Ipomoea pentaphylla. Int Med Arom Plants 1(2):128-131

Manoj A, Urmila A (2008) Anthelmintic activity of Ficus benghalensis. Green Pharm 170:2-14

Messiha NK, El-Dabaa MAT, El-Masry RR, Ahmed SAA (2018) The allelopathic influence of Sinapis alba seed powder (white mustard) on the growth and yield of Vicia faba (faba bean) infected with Orobanche crenata (broomrape). Middle East J Appl Sci 8(2):418-425

Mohsin N, Tariq M, Zaki MJ, Abbasi MW, Imran M (2016) Allelopathic effect of Ficus benghalensis $L$. leaves extract on germination and early seedling growth of maize, mungbean and sunflower. Int J Biol Res 4(1):34-38

Muhammad Z, Majeed A (2014) Allelopathic effects of aqueous extracts of sunflower on wheat (Triticum aestivum L.) and maize (Zea mays L.). Pk. J. Bot. 46(5):1715-1718

Muhammad Z, Ullah SR, Majeed A (2018) Allelopathic activity of leaf extracts of Benjamin fig on germination and early growth potentials of sunflower. Pure App. Bio 7(2):486-493. doi. https://doi.org/10.19045/bspab.70061

Sankar S, Nair AGRI (2001) Sterols and flavonols of Ficus benghalensis. Phytochemistry 9(12):2583-2584

Sharma RS, Chatterji S, Rai KD, Meheta S (2009) Antioxidant activities and phenolic contents of the aqueous extracts of some Indian medicinal plants. J Med PI Res 3(11):944-948

Siddiqui S, Yadav R, Yadav K, Wani FA, Meghvansi MK, Sharma S, Jabeen F (2009) Allelopathic potentialities of different concentration of aqueous leaf extracts of some arable trees on germination and radicle growth of Cicer arietinum Var. - C-235. Glob J Mol Sci 4(2):91-95

Srisawat, U., Panuto W., Kaendee N., Tanuchit S., Itharat A., Lerdvuthisopon N., .Hansaku P. (2010). Determination of phenolic compounds, flavonoids, and antioxidant activities in water extracts of Thai red and white rice cultivars. J Med Assoc Thailand 93 (12):83-91

Taur DJ, Patil RY (2009) Effect of bio-fraction isolated from Ficus bengalensis bark on clonidine induced catalepsy. J Phar Res 2(11):1676-1677

Uma B, Prabhakar K (2009) In vitro antimicrobial activity and phytochemical analysis of Ficus religiosa and Ficus bengalensis against diarrhea lenterotoxigenic E. coli. Ethnobot leafl 13:472-474

Vishnu NT, Anupama AS (2010) Stem bark extraction of Ficus benghalensis for anti- inflammatory activity in animal models. Ind J Biol 48:39-45

Zeng RS, Mallik AU, Luo SM (2008) Allelopathy in sustainable agriculture and forestry. Springer, New York, pp 189-282

\section{Submit your manuscript to a SpringerOpen ${ }^{\circ}$ journal and benefit from:}

- Convenient online submission

- Rigorous peer review

- Open access: articles freely available online

- High visibility within the field

- Retaining the copyright to your article

Submit your next manuscript at $\boldsymbol{\nabla}$ springeropen.com 